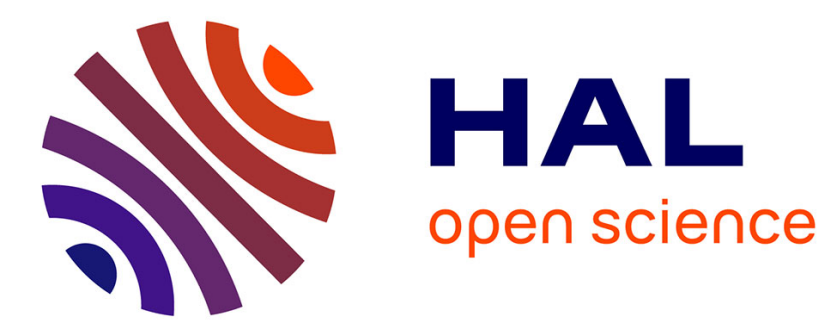

\title{
Cadmium content of phosphate fertilizers used for tobacco production
}

\author{
N. Lugon-Moulin, L. Ryan, P. Donini, L. Rossi
}

\section{To cite this version:}

N. Lugon-Moulin, L. Ryan, P. Donini, L. Rossi. Cadmium content of phosphate fertilizers used for tobacco production. Agronomy for Sustainable Development, 2006, 26 (3), pp.151-155. hal-00886351

\section{HAL Id: hal-00886351 \\ https://hal.science/hal-00886351}

Submitted on 1 Jan 2006

HAL is a multi-disciplinary open access archive for the deposit and dissemination of scientific research documents, whether they are published or not. The documents may come from teaching and research institutions in France or abroad, or from public or private research centers.
L'archive ouverte pluridisciplinaire HAL, est destinée au dépôt et à la diffusion de documents scientifiques de niveau recherche, publiés ou non, émanant des établissements d'enseignement et de recherche français ou étrangers, des laboratoires publics ou privés. 


\title{
Cadmium content of phosphate fertilizers used for tobacco production
}

\author{
N. LUGON-MOULIN ${ }^{a *}$, L. RYAN ${ }^{b}$, P. DONINI ${ }^{a}$, L. ROSSI $^{a}$ \\ a Philip Morris International R\&D, c/o Philip Morris Products S.A., 2000 Neuchâtel, Switzerland \\ ${ }^{b}$ Philip Morris International Management S.A. Leaf Agronomy, 1001 Lausanne, Switzerland
}

(Accepted 18 May 2006)

\begin{abstract}
Tobacco (Nicotiana tabacum L.) leaves may accumulate relatively high levels of cadmium (Cd). The presence of cadmium in soils originates from both natural and anthropogenic sources. In particular, phosphate fertilizers can contain high Cd levels due to the presence of cadmium in the phosphate rock used for their manufacture. In order to investigate the Cd concentration in phosphate fertilizers used for tobacco production, fertilizers were sampled worldwide and analyzed for $\mathrm{Cd}$ and phosphorus. Concentrations ranged from $0.08 \pm 0.14$ to $97.50 \pm 8.74 \mathrm{~g}$ $\mathrm{Cd} / \mathrm{t} \mathrm{P}_{2} \mathrm{O}_{5}$. In some cases, these levels could be explained by the phosphate rock origins. Some of the Cd contained in the fertilizer appeared bioavailable, as determined by diethylenetriaminepentaacetate (DTPA) extraction. Although the bioavailability of the Cd added through these sources to the tobacco plants in the field is not known, the use of fertilizers containing high Cd concentrations should be avoided to protect the soil from gradually accumulating this element and to avoid possible additional $\mathrm{Cd}$ presence in crops. Therefore, while several strategies may be followed to reduce the $\mathrm{Cd}$ concentration in tobacco leaves, the implementation of new agricultural practices such as the screening of the fertilizer source may also contribute to reducing further soil accumulation of $\mathrm{Cd}$.
\end{abstract}

cadmium / fertilizers / phosphate rock / heavy metals / Nicotiana tabacum / tobacco

\section{INTRODUCTION}

Cadmium $(\mathrm{Cd})$ is a potentially very toxic metal (WHO, 1992) which is classified as a Class 1 human carcinogen by the International Agency for Research on Cancer (IARC, 1993). In humans, long-term exposure to $\mathrm{Cd}$ may lead to adverse health effects (Satarug and Moore, 2004; WHO, 1992). Environmental health concerns have been raised as various anthropogenic activities have led to the addition of significant quantities of $\mathrm{Cd}$ to agricultural soils (Wagner, 1993).

In particular, phosphate fertilizers represent a potentially significant source of $\mathrm{Cd}$ to the field. Indeed, they can contain high $\mathrm{Cd}$ levels due to the presence of the metal in the phosphate rock used for their manufacture (McLaughlin et al., 1996). Almost all phosphate fertilizers are produced from phosphate rock. The extent to which Cd originally present in the phosphate rock is transmitted to the final product may partly depend on the manufacturing process (Van Kauwenbergh, 2002). The Cd contents of phosphate rocks from various deposits have been published, and large differences may exist between deposits; especially, but not exclusively, between sedimentary and igneous phosphate rock (Van Kauwenbergh, 1997, 2002). Concentrations of $\mathrm{Cd}$ in several commercial fertilizers have also been monitored (e.g. de López Camelo et al., 1997; Franklin et al., 2005; Gabe and Rodella, 1999; Mishima et al., 2004). The use of high Cd-containing fertilizers may thus cause an accumulation of the metal in the soil, which may in turn be transferred to agricultural products. In this respect, risk assessments have

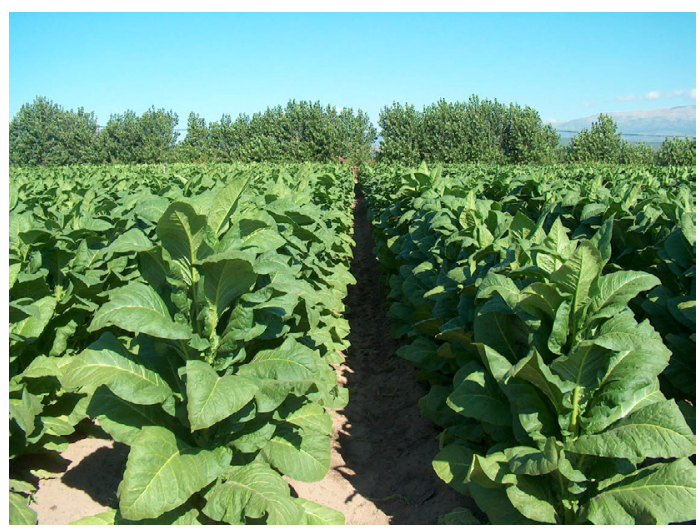

Figure 1. Tobacco (Nicotiana tabacum) field. Phosphate fertilizers are commonly used for tobacco production (picture: courtesy of Luis M. Rodrigues).

been performed for the presence of $\mathrm{Cd}$ in $\mathrm{P}$ fertilizers (e.g. Hutton and de Meeûs, 2001; de Meeûs et al., 2002).

As for the majority of all crops, $\mathrm{P}$ fertilizers are commonly used for tobacco (Nicotiana tabacum L.) production and the repeated use of $\mathrm{Cd}$-containing $\mathrm{P}$ fertilizers may lead to progressive $\mathrm{Cd}$ accumulation in the tobacco field (Fig. 1). For instance, Semu and Singh (1996) reported a significant Cd enrichment of tobacco soils that received high $\mathrm{P}$ fertilizers for many years

* Corresponding author: Nicolas.lugon-moulin@pmintl.com 
and Bielinska et al. (1999) reported that the application of $240 \mathrm{~kg}$ NPK fertilizer/ha in fields (i.e., $30 \mathrm{~kg} \mathrm{~N}, 90 \mathrm{~kg} \mathrm{P} \mathrm{O}_{5}$ and $120 \mathrm{~kg} \mathrm{~K}_{2} \mathrm{O} / \mathrm{ha}$, respectively) under tobacco cultivation led to an enrichment of $\mathrm{Cd}$ in the 5-20 cm topsoil when compared with the use of $700 \mathrm{~kg}$ Flovit fertilizer/ha (NPK formula of Flovit: 4-12-18). The Cd content of the fertilizers used in these studies was not given.

The goal of this survey was to investigate the Cd concentration in various commercial $\mathrm{P}$ fertilizers used for tobacco production and obtain information on the origin of the phosphate rock used to manufacture these fertilizers. This may assist us in identifying fertilizers that may pose a potential problem for $\mathrm{Cd}$ enrichment of tobacco fields. Although it is well known that tobacco leaves may accumulate Cd (Lugon-Moulin et al., 2006), we emphasize that it was not the purpose of this study to assess the impact of $\mathrm{Cd}$-containing $\mathrm{P}$ fertilizers on the $\mathrm{Cd}$ content of tobacco.

\section{METHODS}

Sampling: A total of 36 phosphate fertilizers were sampled in Africa, Asia, Europe and South America; namely in Austria (1), Brazil (6), China (3), the former Yugoslav Republic of Macedonia (FYROM) (2), Germany (1), Greece (12), India (1), Malawi (1), Mozambique (1), Tanzania (1), Thailand (1), Turkey (4) and Vietnam (2). Fertilizers were sampled in triplicate (from different fertilizer bags) except for the single samples in Austria, Germany, Mozambique and Thailand. Fertilizers from Malawi and Mozambique were the same (i.e. the same manufacturer and same formulation; phosphate rock origin not obtained). In the countries sampled, these fertilizers could well be applied on tobacco as well as on other crops. These same fertilizers may also be used for production of tobacco and other crops in other countries. Our sample size may appear small. However, the study aimed uniquely at pointing out whether some fertilizers may pose a potential problem for $\mathrm{Cd}$ field enrichment and whether others may pose less potential problems.

The fertilizers belonged to the following types: monoammonium phosphate (MAP), diammonium phosphate (DAP), single superphosphate (SSP), triple superphosphate (TSP), and compound fertilizers with various amounts of $\mathrm{N}, \mathrm{P}$ and $\mathrm{K}$. The latter included NP, PK and P-only fertilizers (the latter classified here as compound fertilizer). Some fertilizers contained additional nutrients such as boron $(\mathrm{B})$, iron $(\mathrm{Fe})$, magnesium $(\mathrm{Mg})$ or sulfur $(\mathrm{S})$. It is noted that many fertilizers with different formulations may be used for tobacco production. However, it was beyond the scope of this study to exhaustively represent all different $P$ fertilizers that may be used in tobacco fields.

All sub-samples were digested by nitric and sulfuric acids $\left(\mathrm{HNO}_{3}+\mathrm{H}_{2} \mathrm{SO}_{4}\right)$ using method 3.1.1 from the European Union. Total $\mathrm{Cd}$ was measured by graphite-furnace atomic absorption spectrometry (AAS). The P content was determined using method 3.2 from the European Union (gravimetric method using quinoline phosphomolybdate). $\mathrm{P}$ was expressed as $\%$ phosphorus pentoxide $\left(\mathrm{P}_{2} \mathrm{O}_{5}\right)$. In addition, two samples with $\mathrm{Cd}$ concentrations at the upper range of the $\mathrm{Cd}$ distribution were analyzed for diethylenetriaminepentaacetate (DTPA)extractable $\mathrm{Cd}$ to obtain an estimate of bioavailable $\mathrm{Cd}$ following the method of Lindsay and Novell (1978). All samples were sent to an external laboratory (AgroLab Swiss GmbH, Switzerland) for analyses. Cd concentrations were expressed both as $\mathrm{mg} \mathrm{Cd} / \mathrm{kg}$ fertilizer (i.e. on a part per million, ppm basis) and as $\mathrm{g} \mathrm{Cd} / \mathrm{t} \mathrm{P}_{2} \mathrm{O}_{5}$ (Tab. I).

\section{RESULTS AND DISCUSSION}

Cd concentration in the fertilizers ranged from $0.08 \pm 0.14$ to $97.50 \pm 8.74 \mathrm{~g} \mathrm{Cd} / \mathrm{t} \mathrm{P}_{2} \mathrm{O}_{5}$ (Tab. I). The concentration given on a $\mathrm{mg} / \mathrm{kg}$ basis was correlated with that given on a $\mathrm{P}_{2} \mathrm{O}_{5}$ basis (correlation coefficient $r=0.83$; $\mathrm{n}=100$; four samples with total Cd reported as " $<0.012 \mathrm{mg} / \mathrm{kg}$ " were attributed a concentration of $0.00 \mathrm{mg} / \mathrm{kg}$ for calculation purposes), but obvious discrepancies were noticed when there were large differences in $\mathrm{P}_{2} \mathrm{O}_{5}$ content (Tab. I). For example, a NPK fertilizer with a $\mathrm{P}_{2} \mathrm{O}_{5}$ content of $10 \%$ had $3.66 \mathrm{mg} \mathrm{Cd} / \mathrm{kg}$, which translated into $36.68 \mathrm{~g} \mathrm{Cd} / \mathrm{t} \mathrm{P}_{2} \mathrm{O}_{5}$, whereas a $\mathrm{P}$ fertilizer with $46 \% \mathrm{P}_{2} \mathrm{O}_{5}$ had a Cd concentration 2.5 times higher on a $\mathrm{mg} / \mathrm{kg}$ basis $(8.98 \mathrm{mg} /$ $\mathrm{kg}$ ), but a ca. two-fold lower concentration on a $\mathrm{P}_{2} \mathrm{O}_{5}$ basis (19.55 g Cd/t $\mathrm{P}_{2} \mathrm{O}_{5}$ ).

The $\mathrm{Cd}$ concentration measured on a $\mathrm{mg} / \mathrm{kg}$ basis was weakly correlated with the $\mathrm{P}_{2} \mathrm{O}_{5}$ content (correlation coefficient, $r=0.37 ; \mathrm{n}=100$; four samples with total $\mathrm{Cd}$ reported as " $<0.012 \mathrm{mg} / \mathrm{kg}$ " were attributed a concentration of $0.00 \mathrm{mg} / \mathrm{kg}$ for calculation purposes) because different phosphate rocks used in the fertilizer manufacturing can have different $\mathrm{Cd}$ concentrations (Van Kauwenbergh, 2002). Therefore, the phosphate rock origins of the fertilizers analyzed in this study were determined, when possible, and put in relation to the $\mathrm{Cd}$ content of the fertilizer. For discussion purposes, fertilizers were separated into three classes corresponding to the proposed limits to be gradually phased in by the European Union (EU); that is, limits of 60, 40 and $20 \mathrm{~g} \mathrm{Cd} / \mathrm{t} \mathrm{P}_{2} \mathrm{O}_{5}$ (Hutton and de Meeûs, 2001). Other limits exist or have been proposed (e.g. see Van Kauwenbergh, 2002), but it is not the purpose of the present study to discuss them.

Most fertilizers had $<20 \mathrm{~g} \mathrm{Cd} / \mathrm{P}_{2} \mathrm{O}_{5}$ (55.6\%; Tab. I). Some had a very low $\mathrm{Cd}$ content (about $1 \mathrm{~g} \mathrm{Cd} / \mathrm{P}_{2} \mathrm{O}_{5}$ ), like the fertilizer manufactured using rock from the Kola Peninsula (Russia), and the one manufactured with phosphate rock from central Finland (+ $10 \%$ from Kola Peninsula). These two phosphate rocks originated from igneous phosphate deposits, which usually contain lower amounts of Cd than sedimentary phosphate deposits (Van Kauwenbergh, 1997, 2002). A phosphate rock sample from Finland (Siilinjarvi) had $<2 \mathrm{mg} \mathrm{Cd} / \mathrm{kg}$ while samples from the Kola Peninsula had Cd concentrations ranging from 0.3 to $2 \mathrm{mg} / \mathrm{kg}$ (Van Kauwenbergh, 2002). The two fertilizers sampled in Vietnam both had low Cd levels $(<5 \mathrm{~g} \mathrm{Cd} / \mathrm{t}$ $\mathrm{P}_{2} \mathrm{O}_{5}$ ). For one of them, the phosphate rock originated from the Lao Cai quarry, the largest phosphate rock deposit in Vietnam. A fertilizer made from phosphate rock originating from Kaiyang (Guizhou province), a large phosphorus mine in China, contained $18.83 \mathrm{~g} \mathrm{Cd} / \mathrm{t}_{2} \mathrm{O}_{5}$. Low $\mathrm{Cd}$ was reported in the sedimentary phosphate rock from the Kaiyang deposit, although it was based on a single sample $(<2 \mathrm{mg} / \mathrm{kg}$; Van Kauwenbergh, 2002). The fertilizers for which no information was available on the phosphate rock origin all fell under the limit of $20 \mathrm{~g} \mathrm{Cd} / \mathrm{t} \mathrm{P}_{2} \mathrm{O}_{5}$. Moreover, two fertilizers made from phosphate rocks from Algeria and/or Tunisia fell into this class, 
Table I. Cadmium concentration of fertilizers, with fertilizer type, phosphate rock origin, and country of sampling. Fertilizer type: N, P and K stand for nitrogen, phosphorus and potassium, respectively. MAP, DAP, TSP and SSP = monoammonium phosphate, diammonium phosphate, triple superphosphate and single superphosphate, respectively. The fertilizers may contain additional nutrients. Country of sampling: examples, the list of countries is not meant to be complete. Samples 19, 20, 33 and 34 and DTPA-Cd: one replicate only; 3 replicates for all other fertilizer samples.

Fertilizer type: phosphate rock origin $\quad$ Country of sampling (and where used for $\quad \mathrm{Cd} \mathrm{mg/kg} \quad \mathrm{g} \mathrm{Cd} / \mathrm{t} \mathrm{P}_{2} \mathrm{O}_{5} \quad$ DTPA-Cd mg/kg tobacco production)

1. DAP: -

2. DAP: -

3. DAP: Algeria, Morocco

4. DAP: Algeria

5. MAP: Algeria, Tunisia

6. MAP: Russia, Peninsula of Kola

7. MAP: USA, Central Florida (sediment form)

8. NP: Tunisia

9. NP: Morocco

10. NP: Syrian phosphate

11. NPK: Dolomite rock

12. NPK: Dolomite rock

13. NPK: Dolomite rock

14. NPK: Jordan

15. NPK: Finland (Central): 90\%; $10 \%$ from Russia, Kola Peninsula

16. NPK: -

17. NPK: -

18. NPK: -

19. NPK: -

20. NPK: China (Kaiyang county, Guizhou province)

21. NPK: Tunisia, Morocco

22. NPK: Morocco

23. NPK: Morocco, mine location: Khouribga

24. NPK: Morocco, mine location: Khouribga

25. NPK: Russia

26. NPK: Russia

27. NPK: Syrian phosphate

28. NPK: Syrian phosphate

29. NPK: Syrian phosphate

30. NPK: USA, Israel (Russia?)

31. P: Syrian phosphate

32. P: Syrian phosphate

33. PK: -

34. PK: Syrian phosphate

35. SSP: Vietnam, Lao Cai quarry, Lao Cai province

36. TSP: Israel, Desert of Negev (sediment form, type ZIN)
China

Vietnam (China, Laos)

Turkey (USA, Russia, Lithuania) India

Turkey (Greece, Russia, Europe)

Brazil

Brazil

Turkey (Brazil, China, Greece, Russia)

Greece

Greece

Greece

FYROM

FYROM

Greece (FYROM)

Tanzania

China

China

Malawi

Mozambique

Thailand (China)

Turkey (Greece, Tunisia, China)

Greece

Brazil

Brazil

Greece

Greece

Greece

Greece

Greece

Brazil

Greece

Greece

Germany

Austria (Hungary, Serbia, Croatia, Bosnia)

Vietnam (Cambodia, Laos)

Brazil $\begin{array}{cc}2.22 \pm 0.05 & 4.46 \pm 0.05 \\ 1.34 \pm 0.43 & 3.00 \pm 1.01 \\ 9.36 \pm 0.75 & 21.94 \pm 1.53 \\ 6.12 \pm 0.95 & 13.29 \pm 4.76 \\ 2.78 \pm 4.82 & 6.27 \pm 10.86 \\ 0.14 \pm 0.21 & 0.27 \pm 0.40 \\ 50.92 \pm 4.57 & 97.50 \pm 8.74\end{array}$

$10.35 \pm 1.35 \quad 50.97 \pm 7.28$

$3.12 \pm 0.49 \quad 19.87 \pm 3.52$

$2.49 \pm 0.41 \quad 15.71 \pm 3.03$

$1.05 \pm 0.22 \quad 9.05 \pm 0.83$

$2.49 \pm 0.16 \quad 19.07 \pm 2.15$

$0.02 \pm 0.04 \quad 0.08 \pm 0.14$

$13.79 \pm 0.88 \quad 59.89 \pm 7.73$

$0.22 \pm 0.23 \quad 1.04 \pm 0.99$

$0.60 \pm 0.05 \quad 5.54 \pm 0.41$

$1.51 \pm 0.51 \quad 9.56 \pm 3.15$

$0.30 \pm 0.03 \quad 1.15 \pm 0.12$

$0.21 \quad 0.79$

$1.96 \quad 18.83$

$5.28 \pm 0.28 \quad 29.52 \pm 0.88$

$0.80 \pm 0.18 \quad 6.10 \pm 1.94$

$10.64 \pm 2.6448 .63 \pm 12.22$

$11.45 \pm 0.6765 .22 \pm 10.41$

$3.23 \pm 0.68 \quad 20.15 \pm 4.51$

$3.66 \pm 0.8636 .68 \pm 11.62$

$2.25 \pm 0.05 \quad 19.56 \pm 0.20$

$3.51 \pm 0.99 \quad 23.93 \pm 7.03$

$4.25 \pm 0.06 \quad 28.49 \pm 0.67$

$9.10 \pm 3.00 \quad 61.36 \pm 19.30$

$8.98 \pm 0.94 \quad 19.55 \pm 1.90$

$5.51 \pm 1.20 \quad 20.11 \pm 4.73$

$3.19 \quad 23.90$

$1.19 \quad 20.06$

$0.65 \pm 0.01 \quad 3.35 \pm 0.09$

$26.71 \pm 0.98 \quad 57.76 \pm 3.25 \quad 16.65(65 \%)$ although deposits from North Africa may contain high Cd levels. Indeed, an average Cd concentration of $39.5 \mathrm{mg} / \mathrm{kg}$ (range: $30-56 \mathrm{mg} / \mathrm{kg}, \mathrm{n}=4$ ) was reported for phosphate rocks from mines in Tunisia, and Cd ranged from 12 to $32 \mathrm{mg} \mathrm{Cd} / \mathrm{kg}(\mathrm{n}=$ 3) for Algerian deposits (Van Kauwenbergh, 2002). However, one of these two fertilizers (number 5 in Tab. I) showed a fairly large variation between replicates. Two sub-samples had essentially no $\mathrm{Cd}(<0.012 \mathrm{mg} / \mathrm{kg})$, while the third one had $8.34 \mathrm{mg}$ $\mathrm{Cd} / \mathrm{kg}$, i.e. $43.10 \mathrm{~g} \mathrm{Cd} / \mathrm{t} \mathrm{P}_{2} \mathrm{O}_{5}$. Moreover, another fertilizer made from phosphate rock from Tunisia had $50.97 \mathrm{Cd} / \mathrm{P}_{2} \mathrm{O}_{5}$.

A total of 29 fertilizers $(80.6 \%)$ were under the limit of $40 \mathrm{~g} \mathrm{Cd} / \mathrm{t}_{2} \mathrm{O}_{5}$, which included two fertilizers made from rock 
from Russia, although the exact deposit location was not obtained (Tab. I). All fertilizers made from Syrian phosphate had $<40 \mathrm{~g} \mathrm{Cd} / \mathrm{t}_{2} \mathrm{O}_{5}$. A phosphate rock sample from Syria (Khneifiss deposit) contained $3 \mathrm{mg} \mathrm{Cd} / \mathrm{kg}$ (Van Kauwenbergh, 2002).

The majority of the fertilizers analyzed here had $<60 \mathrm{~g} \mathrm{Cd} /$ t $\mathrm{P}_{2} \mathrm{O}_{5}(91.7 \%)$. Some were close to this limit, like the fertilizer made from phosphate rock from Jordan $\left(59.89 \mathrm{~g} \mathrm{Cd} / \mathrm{t}_{2} \mathrm{O}_{5}\right)$. Phosphate rock analyzed from this country yielded from 3 to $12 \mathrm{mg} \mathrm{Cd} / \mathrm{kg}$ (Van Kauwenbergh, 2002). The fertilizer made from phosphate rock originating from the Negev desert in Israel also had a relatively high Cd content $\left(57.76 \mathrm{~g} \mathrm{Cd} / \mathrm{tP}_{2} \mathrm{O}_{5}\right)$, which appears consistent with the reporting of an average $\mathrm{Cd}$ concentration of $30.77 \mathrm{mg} / \mathrm{kg}$ for this region (Van Kauwenbergh, 2002).

Only three fertilizers had a Cd concentration over the limit of $60 \mathrm{~g} \mathrm{Cd} / \mathrm{P}_{2} \mathrm{O}_{5}(8.3 \%)$. The phosphate rock used to manufacture these "high-Cd" fertilizers originated from Khouribga (Morocco) and Central Florida (USA). Cd concentrations reported in phosphate rock from the mine of Khouribga ranged from 3-27 mg/kg (average: $15.06 \mathrm{mg} / \mathrm{kg} ; \mathrm{n}=10$ ), and those from central Florida, 3-20 mg/kg (average: $9.13 \mathrm{mg} / \mathrm{kg} ; \mathrm{n}=27$ ) (Van Kauwenbergh, 2002).

The fertilizer with the highest reported concentration (97.50 $\mathrm{g} \mathrm{Cd} / \mathrm{t}_{2} \mathrm{O}_{5}$ ) was a MAP fertilizer whose phosphate rock was from Central Florida (Tab. I). Interestingly, another MAP with the same formulation and sampled in the same country, but differing in the phosphate rock origin (Peninsula of Kola, Russia), had only $0.27 \mathrm{~g} \mathrm{Cd} / \mathrm{t}_{2} \mathrm{O}_{5}$ (Tab. I). This large (361 times) difference obtained for two fertilizers of the same type and formulation and commercialized in the same country suggests that the screening of fertilizers' sources to avoid "high-Cd" fertilizers may contribute to avoiding further $\mathrm{Cd}$ soil contamination.

The potentially bioavailable fraction of $\mathrm{Cd}$ in two fertilizers containing relatively high levels of $\mathrm{Cd}$ was estimated (Tab. I). In both cases, $>50 \%$ of the total Cd was extractable by DTPA (50.3\% and $65 \%$, respectively), therefore both have considerable potential bioavailability. However, it is not known to what extent the $\mathrm{Cd}$ added to the fields through the fertilizers analyzed in this study might have been available for uptake by tobacco. $\mathrm{Cd}$ availability to the plant may be affected by complex genotype $\mathrm{X}$ environment interactions, the study of which was beyond the scope of this work. Few studies on the transfer efficiency of $\mathrm{Cd}$ from fertilizers to plants under field conditions are reported in the literature (Huang et al., 2004). Some studies suggest that $\mathrm{P}$ fertilizer application may increase the $\mathrm{Cd}$ concentrations in tobacco leaves (Miele et al., 2002; Semu and Singh, 1996; reviewed in Lugon-Moulin et al., 2004), but different fertilizers, though having a similar $\mathrm{Cd}$ content, may have different impacts on the final concentration in the tobacco leaves. For example, the use of fertilizers with different $\mathrm{N}$ forms can lead to significant differences in the $\mathrm{Cd}$ concentration of tobacco leaves (Phu Lich et al., 1990; Tsadilas et al., 2005). Furthermore, as tobacco is subdivided into many different cultivars, and is cultivated worldwide on different soils and under different agro-climatic conditions, the availability to tobacco of $\mathrm{Cd}$ added through fertilizers may vary depending on various conditions. It is indeed known that various factors such as soil $\mathrm{pH}$ may affect Cd uptake by tobacco (Lugon-Moulin et al., 2004; Tsadilas et al., 2005).

\section{CONCLUSION}

By sampling fertilizers in various countries and continents, we showed that the range of $\mathrm{Cd}$ concentration in phosphate fertilizers used for tobacco production varies considerably, despite our limited sample size. A more extensive sampling of $\mathrm{Cd}$ and $\mathrm{P}$ concentration in phosphate rock deposits and in the fertilizers made from such deposits, also taking into account the manufacturing process, would be needed to obtain a comprehensive picture of the $\mathrm{Cd}$ concentration and its variability in such deposits and fertilizer samples. Nevertheless, fertilizers appear to be one of the sources that can contribute to adding new $\mathrm{Cd}$ to agricultural soil. These additions can be controlled/ prevented to some extent, by selecting the use of "low" Cd-containing fertilizers in tobacco production.

Ackowledgments: We kindly thank DIMON Inc. (now part of Alliance One International, Inc.) for their assistance in supplying the fertilizer samples and non-proprietary information on fertilizers, and Luis M. Rodrigues (Philip Morris International) who kindly provided the picture of the tobacco field.

\section{REFERENCES}

Bielinska E.J., Magierski J., Wisniewski J. (1999) The effect of mineral fertilization on the content of some heavy metals in soil under tobacco, Ann. Univ. Mariae Curie Skodowska E 54, 153-159.

de López Camelo L.G., De Miguez S.R., Marbán L. (1997) Heavy metals input with phosphate fertilizers used in Argentina, Sci. Total Environ. 204, 245-250.

de Meeûs C., Eduljee G.H., Hutton M. (2002) Assessment and management of risks arising from exposure to cadmium in fertilisers. I. Sci. Total Environ. 291, 167-187.

Franklin R.E., Duis L., Brown R., Kemp T. (2005) Trace element content of selected fertilizers and micronutrient source materials, Commun. Soil Sci. Plan. 36, 1591-1609.

Gabe U., Rodella A.A. (1999) Trace elements in Brazilian agricultural limestones and mineral fertilizers, Commun. Soil Sci. Plan. 30, 605-620.

Huang B., Kuo S., Bembenek R. (2004) Availability of cadmium in some phosphorus fertilizers to field-grown lettuce, Water Air Soil Poll. $158,37-51$.

Hutton M., de Meeûs C. (2001) Analysis and conclusions from member states' assessment of the risk to health and the environment from cadmium in fertilisers, Final report (European Commission - Enterprise DG), pp. 1-134.

IARC (1993) Beryllium, cadmium, mercury, and exposures in the glass manufacturing industry, IARC Monographs on the Evaluation of Carcinogenic Risks to Humans and their Supplements 58, 1-444.

Lindsay W.L., Novell W.A. (1978) Development of a DTPA soil test for zinc, iron, manganese and copper, Soil Sci. Soc. Am. J. 42, 421428.

Lugon-Moulin N., Zhang M., Gadani F., Rossi L., Koller D., Krauss M.R., Wagner G.J. (2004) Critical review of the science and options for reducing cadmium in tobacco (Nicotiana tabacum L.) and other plants, Adv. Agron. 83, 111-180. 
Lugon-Moulin N., Martin F., Krauss M.R., Ramey P.B., Rossi L. (2006) Cadmium concentration in tobacco (Nicotiana tabacum L.) from different countries and its relationship with other elements, Chemosphere 63, 1074-1086.

McLaughlin M.J., Tiller K.G., Naidu R., Stevens D.P. (1996) Review: the behaviour and environmental impact of contaminants in fertilizer, Aust. J. Soil Res. 34, 1-54.

Miele S., Barbayannis N., Bargiacchi E., Kosmidou O., Matsi T., Olivieri O., Pangos N., Tsotsolis N. (2002) Phosphate application and tobacco heavy metal leaf concentrations. Results of the 3-year E.U. funded 96/T/35 Project in Italy and Greece, CORESTA Congress, New Orleans, USA, September 2002.

Mishima S.I., Kimura R., Inoue T. (2004) Estimation of cadmium load on Japanese farmland associated with the application of chemical fertilizers and livestock excreta, Soil Sci. Plant Nutr. 50, 263-267.

Phu Lich N., Truhaut R., Claude J.R., Tancogne J., Schiltz P. (1990) Le cadmium et le tabac (cadmium and tobacco), Bull. ARN 50-64.

Satarug S., Moore M.R. (2004) Adverse health effects of chronic exposure to low-level cadmium in foodstuffs and cigarette smoke, Environ. Health Persp. 112, 1099-1103.
Semu E., Singh B.R. (1996) Accumulation of heavy metals in soils and plants after long-term use of fertilizers and fungicides in Tanzania, Fert. Res. 44, 241-248.

Tsadilas C.D., Karaivazoglou N.A., Tsotsolis N.C., Stamatiadis S., Samarasa V. (2005) Cadmium uptake by tobacco as affected by liming, $\mathrm{N}$ form, and year of cultivation, Environ. Pollut. 134, 239246.

Van Kauwenbergh S.J. (1997) Cadmium and Other Minor Elements in World Resources of Phosphate Rock, The International Fertilizer Society Proceeding, p. 400.

Van Kauwenbergh S.J. (2002) Cadmium content of phosphate rocks and fertilizers, International Fertilizer Industry Association (IFA) Technical Conference, Chennai, India, September 2002.

Wagner G.J. (1993) Accumulation of cadmium in crop plants and its consequences to human health, Adv. Agron. 51, 173-212.

WHO (World Health Organization) (1992) Cadmium, Environmental Health Criteria 134, 1-280.

To access this journal online: www.edpsciences.org 